\title{
EVALUATION OF SELECTED FEEDS DIFFERING IN DIETARY LIPIDS LEVELS IN FEEDING JUVENILES OF WELS CATFISH, SILURUS GLANIS L.
}

\author{
Jan MAZURKIEWICZ* , Antoni PRZYBYE, and Janusz GOLSKI \\ Division of Inland Fisheries and Aquaculture \\ University of Life Sciences in Poznań, Poland
}
Przybył A., Mazurkiewicz J., Golski J. 2008. Evaluation of selected feeds differing in dietary lipids levels in feeding juveniles of wels catfish, Silurus glanis L. Acta Ichthyol. Piscat. 38 (2): 91-96.

Background. Development of modern aquaculture and the increasing consumer demand provoke improvements in the complex breeding technologies of economically valuable fish species. Wels catfish, Silurus glanis L. (known also as the European catfish), because of its breeding and consumption values, becomes an increasingly common object of breeding. The objective of the presented work was the evaluation of selected feeds differing in dietary lipids levels applied in rearing the wels catfish fry under controlled conditions.

Materials and Methods. The feeding trial (60 days) was carried out with the wels catfish fry, weighing on average $55 \mathrm{~g}$. The experiment was conducted under controlled conditions in an aquarium hall in 60-L flow-through tanks. During the growth test, the fish were given four commercial feeds of the same protein amount (45\%) and graded fat levels $(15 \%, 20 \%, 25 \%$, and $30 \%)$. In the final evaluation of the feeding tests, the following rearing effectiveness indices were used: food conversion ratio (FCR), specific growth rate (SGR), protein efficiency ratio (PER), protein retention (PR), lipid retention (LR), and survival rate (SR). Conclusions were drawn on the basis of statistical analysis using Statistica computer software.

Results. The wels catfish fed 20\%-fat-content feed attained the highest individual weights. The other treatments yielded statistically significantly lower $(P \leq 0.05)$ body weights. No statistically significant differences were found between the mean values of the specific growth rate (SGR). The values of feed conversion ratio (FCR) and protein efficiency ratio (PER) were approximately equal in the individual groups. The protein retention attained values from $28.2 \%$ to $33.0 \%$, while fat retention ranged from $11.8 \%$ to $24.2 \%$. No mortalities were recorded. The amount of fat in all groups increased significantly after the termination of the growth. The increase of fat amount in the feed was not correlated with the growth of fat amount in the fish body. The levels of the other body components increased, but no differences between the groups were found.

Conclusions. Differentiated amounts of dietary lipids in the diet did not exert any effect on the rate of fish growth or on the proper utilization of the nutritive components in feeds. The present results emphasize the complexity of the wels catfish nutrition study and the need for further investigation in this field. From a practical point of view, a good understanding of the species requirement for dietary lipids would be of prime interest for fish farmers to use balanced feed optimized for particular fish stages.

Keywords: wels catfish, European catfish, Silurus glanis, feeding, dietary lipids

\section{INTRODUCTION}

Development of modern aquaculture and the increasing consumer demand provoke improvements in the complex breeding technologies of economically valuable fish species. Wels catfish, Silurus glanis L. (known also as the European catfish), because of its breeding and consumption values, becomes an increasingly common object of breeding. The pond breeding technology of the catfish was developed in the early 20th century in Hungary and it was later adopted in Germany, Russia, Czech Republic,
Slovakia, and Poland, reaching France relatively recently (Vallod 1987, Proteau et al. 1996). Now the wels catfish is cultured in the circulation systems, substantially shortening the production cycle (from hatch to a market-size fish of about $1.5 \mathrm{~kg}$ ) to the period of 7-8 months (Ulikowski et al. 1998, Linhart et al. 2002, Ulikowski $2003,2005)$. The improvement of fish feeding was another direction of the catfish breeding technology improvement, focusing on optimization of the content of proteins, fats, carbohydrates, vitamins, amino acids (essential ones

\footnotetext{
* Correspondence: Dr Jan Mazurkiewicz, Katedra Rybactwa Śródlądowego i Akwakultury, Uniwersytet Przyrodniczy w Poznaniu, ul. Wojska Polskiego 71c, 60-625 Poznań, Poland, phone: (+4861) 848-77-22, fax: (+4861) 848-77-06, e-mail: karp@au.poznan.pl
} 
in particular), and micro- and macro-elements. The fats contained in the feed are equally important as proteins in nutrition of many fish species, including wels catfish. They are not only the source of metabolic energy, essential (for fish) fatty acids, hormone precursors, and phospholipids. The latter are important components of cytoplasmic membranes (Has-Schön et al. 2004). Fats are also needed as solvents for vitamins (A, D, E and K), necessary for the correct functioning of organisms. A shortage of lipids in the feed, particularly the essential fatty acids, may lead to a retardation of fish growth, or cause a dysfunction of pigmentation, anaemia, necrosis of fins, degenerative changes in liver and spleen, and in extreme cases, it may lead to an increased mortality of fishes.

The objective of the presented work was the evaluation of selected feeds differing in dietary lipids levels, used for rearing wels catfish fry under controlled conditions.

\section{MATERIAL AND METHODS}

Fish and rearing facilities. The growth test was carried out between 20 January and 20 March 2006 (60 days). The wels catfish fry, weighing $55 \mathrm{~g}$ on the average, were acquired from the Kuźniczka Fish Farm at Wieleń. The experiment was performed under controlled conditions (Aquarium Compound, Division of Inland Fisheries and Aquaculture, University of Life Sciences in Poznań) in an open system of water supply. Tap water, used in the system, was de-chlorinated using active carbon filter. The main element of the water system installation was the equalizing tank $\left(2.4 \mathrm{~m}^{3}\right)$ with a heater, thermostat, and the HIBLOW HP-60 aerator. During the experiment, the physico-chemical parameters of water were maintained on relatively constant optimal levels for catfish fry (temperature: $22-23^{\circ} \mathrm{C}$; oxygen saturation above $70 \%$ ) and constantly monitored by a microcomputer oxymeter ELMETRON CO-315.

Catfish juveniles were placed in 60-L, constant-flow tanks $\left(0.3 \mathrm{~L} \cdot \mathrm{min}^{-1}, 5\right.$ total water exchanges within $\left.24 \mathrm{~h}\right)$. Every day (at $09.00 \mathrm{~h}$ ), the tanks were cleaned by removing excrements and left-over feed using a water siphon. Experimental feeds were dosed around the clock (24 h) using automatic belt feeders. In first and second growth test decades the daily feed ration was $2.5 \%$ of the fish biomass. It was $2.0 \%$ in third and fourth decades and $1.5 \%$ in last two growth test decades.

The experiment was carried out in four treatments, each in three replications. Each tank was stocked with 10 fish.

Data collection and calculations. Every 10 days all fish in each tank were weighed (to the nearest $0.1 \mathrm{~g}$ ) using WPE 2000 electronic scale (RADWAG Radom, Poland). The mean individual fish body mass was calculated by dividing the fish biomass by fish number. The weight control served also for the determination of the values of rearing indices.

The following parameters were calculated: specific growth rate $\left(\mathrm{SGR}=100 \cdot\left(\ln w_{t}-\ln w_{o}\right) \cdot t^{-1}\right)$, food conversion ratio $\left(\mathrm{FCR}=F \cdot\left(w_{t}-w_{o}\right)^{-1}\right)$, protein efficiency ratio $\left(\mathrm{PER}=\left(w_{t}-w_{o}\right) \cdot(F \cdot \mathrm{PD})\right)\left(\right.$ where; $w_{o}$ and $w_{t}$ : the initial and the final average weight; $t$ : number of days of feeding trial; $F$ : the total amount of feed per fish consumed during growth test; PD: the protein content of the diets); the survival rate $(\mathrm{SR}=($ final number of fish $\cdot 100) \cdot$ initial number of fish $\left.{ }^{-1}\right)$; protein retention $(\mathrm{PR}=($ final protein contain in fish body - initial protein contain in fish body) $\cdot 100 \cdot$ protein intake $\left.{ }^{-1}\right)$; and lipid retention $(\mathrm{LR}=$ (final lipid contain in fish body - initial lipid content in fish body) $\cdot 100 \cdot$ lipid intake ${ }^{-1}$ ).

Before the commencement and after the termination of the growth test, fish samples were randomly taken in order to determine the basic chemical composition of fish bodies. The sampled catfish were enthanised, using Propiscin (Siwicki 1984) overdose and decapitated. Subsequently, fish bodies were ground and homogenized, and in the obtained material, the following determination were made: dry mass (in an oven at $105^{\circ} \mathrm{C}$ for $12 \mathrm{~h}$ ), protein (Kjel-Foss Automatic 16210 analyzer), crude fat (Soxhlet method; drying at $60^{\circ} \mathrm{C}, 12 \mathrm{~h}$ of extraction with paraffin ether), ash (combustion at $550^{\circ} \mathrm{C}$ for $12 \mathrm{~h}$, Linn Electro-Therm stove).

The results were statistically analyzed using the Statistica 5 PL software. Mean results per tank were subjected to one-way analysis of variance (ANOVA). Homogenous groups were determined with the Duncan multiple range test. The level of significance was $P \leq 0.05$, and the results are presented as mean \pm standard deviation of the mean.

Feeds. During the growth test, the fish were given four commercial feeds of Aller Aqua Polska Co. Ltd., Golub-Dobrzyń:

Aller 45/15 (protein 45\%, fat 15\%), treatment 15 ,

Aller Safir (protein $45 \%$, fat 20\%), treatment 20,

Aller Avant (protein 46\%, fat 25\%), treatment 25,

Aller Elips (protein 45\%, fat 30\%), treatment 30 .

The characteristics of the particular feeds based on the producer's data are shown in Table 1 . All feeds contained: fish products, oils and fats, cereal grains, oil seed by-products, cereals, and minerals. The Aller 45/15 feed included additionally blood meal, while the Aller Elips feed had an addition of blood meal and fishmeal LT.

\section{RESULTS}

The feeding with feeds containing variable content of fat had an effect on the mass increments of fish body. Starting from the 20th day of the growth test, the highest mean individual weights were reached by catfish fed feed 20 , while in the remaining treatments, statistically significantly lower $(P \leq 0.05)$ body weights of fish were recorded. In treatment 15 , the fish showed a high growth differentiation within the group confirmed by high standard deviations for body weight (Table 2). No statistically significant differences were found between the mean values of the specific growth rate (SGR). The values of feed conversion ratio (FCR) and protein efficiency ratio (PER) were approximately equal in the individual groups (no statistically significant differences) (Table 3). The index of protein retention in fish body ranged from $28.2 \%$ (treatment 30 ) to 
$33.0 \%$ (treatment 15 ), on the other hand, fat retention was significantly more variable, attaining values from $11.8 \%$ in treatment 25 to $24.2 \%$ in treatment 15 . There were no fish mortalities recorded during the growth test.

Results of chemical analyses of the catfish bodies indicated a significant increase of the amount of fat in all groups after the termination of the growth test and an absence of a correlation between the increase of fat amount in the feed and the growth of fat amount in the fish body. The levels of the remaining body components increased, as compared with the size on the day of the growth test start, on the other hand, no differences between the groups were found after the termination of the experiment (Table 4).

Table 1

Feed characteristics

\begin{tabular}{lcccc}
\hline \multirow{2}{*}{ Parameter } & \multicolumn{3}{c}{ Feed } \\
\cline { 2 - 5 } & Aller 45/15 & Aller Safir & Aller Avant & Aller Elips \\
\hline Protein [\%] & 45 & 45 & 46 & 46 \\
Fat [\%] & 15 & 20 & 25 & 30 \\
Carbohydrates [\%] & 21 & 16 & 15 & 11 \\
Ash [\%] & 8 & 8 & 7 & 8 \\
Fibre [\%] & 2.5 & 2 & 1 & 1 \\
Gross energy [MJ kg ${ }^{-1}$ ] & 20.5 & 21.6 & 23.1 & 24.7 \\
Digestible energy [MJ kg ${ }^{-1}$ ] & 16.2 & 17.3 & 18.8 & 20.5 \\
Nitrogen [\% of dry mass] & 7.8 & 8.42 & 7.91 & 7.41 \\
Phosphorus [\% of dry mass] & 1.1 & 1.16 & 0.97 & 0.95 \\
Vitamin A [IU] (in 1 kg of feed) & 2500 & 2500 & 2500 & 2500 \\
Vitamin D [IU] (in 1 kg of feed) & 500 & 500 & 500 & 500 \\
Vitamin E [mg] (in 1 kg of feed) & 100 & 100 & 150 & 300 \\
\hline
\end{tabular}

Table 2

Changes of mean individual fish weight $[\mathrm{g}]$ during the growth test ${ }^{1}$

\begin{tabular}{lcccc}
\hline \multirow{2}{*}{$\begin{array}{c}\text { Days of growth } \\
\text { test }\end{array}$} & \multicolumn{4}{c}{ Treatment } \\
\cline { 2 - 5 } & 15 & 20 & 25 & 30 \\
\hline 0 & $52.9 \pm 2.4^{\mathrm{a}}$ & $57.5 \pm 1.6^{\mathrm{a}}$ & $54.9 \pm 2.2^{\mathrm{a}}$ & $54.1 \pm 0.5^{\mathrm{a}}$ \\
10 & $75.2 \pm 6.8^{\mathrm{a}}$ & $87.0 \pm 3.9^{\mathrm{a}}$ & $85.2 \pm 4.1^{\mathrm{a}}$ & $82.5 \pm 2.1^{\mathrm{a}}$ \\
20 & $111.1 \pm 12.3^{\mathrm{a}}$ & $128.9 \pm 7.0^{\mathrm{b}}$ & $116.9 \pm 2.1^{\mathrm{a}}$ & $114.6 \pm 4.9^{\mathrm{a}}$ \\
30 & $159.3 \pm 17.0^{\mathrm{a}}$ & $175.2 \pm 5.9^{\mathrm{b}}$ & $156.2 \pm 8.3^{\mathrm{a}}$ & $158.0 \pm 4.8^{\mathrm{a}}$ \\
40 & $181.6 \pm 23.0^{\mathrm{a}}$ & $209.1 \pm 13.4^{\mathrm{b}}$ & $193.0 \pm 5.2^{\mathrm{a}}$ & $186.3 \pm 3.7^{\mathrm{a}}$ \\
50 & $215.7 \pm 17.3^{\mathrm{a}}$ & $238.8 \pm 8.9^{\mathrm{b}}$ & $216.6 \pm 5.8^{\mathrm{a}}$ & $217.0 \pm 14.7^{\mathrm{a}}$ \\
60 & $250.1 \pm 23.3^{\mathrm{a}}$ & $271.0 \pm 4.2^{\mathrm{b}}$ & $247.0 \pm 8.7^{\mathrm{a}}$ & $245.5 \pm 9.4^{\mathrm{a}}$ \\
\hline
\end{tabular}

${ }^{1}$ Values are means \pm standard deviation from triplicate groups of fish, and the means in each row with the same superscript are not significantly different $(P \leq 0.05)$.

Specific growth rate (SGR), food conversion ratio (FCR), protein efficiency ratio (PER),

Table 3 protein retention (PR), lipid retention (LR), and survival rate (SR) in catfish fry during 60 days growth test ${ }^{1}$

\begin{tabular}{lcccc}
\hline \multirow{2}{*}{ Parameter } & \multicolumn{4}{c}{ Treatment } \\
\cline { 2 - 5 } & 15 & 20 & 25 & 30 \\
\hline SGR [\% d $\left.{ }^{-1}\right]$ & $2.65 \pm 0.08^{\mathrm{a}}$ & $2.58 \pm 0.07^{\mathrm{a}}$ & $2.51 \pm 0.09^{\mathrm{a}}$ & $2.52 \pm 0.08^{\mathrm{a}}$ \\
FCR & $0.94 \pm 0.03^{\mathrm{a}}$ & $1.03 \pm 0.08^{\mathrm{a}}$ & $1.04 \pm 0.02^{\mathrm{a}}$ & $1.05 \pm 0.06^{\mathrm{a}}$ \\
PER & $2.78 \pm 0.08^{\mathrm{a}}$ & $2.55 \pm 0.19^{\mathrm{a}}$ & $2.51 \pm 0.05^{\mathrm{a}}$ & $2.50 \pm 0.15^{\mathrm{a}}$ \\
PR [\%] & $33.0 \pm 1.22^{\mathrm{a}}$ & $31.2 \pm 2.03^{\mathrm{a}}$ & $29.3 \pm 1.98^{\mathrm{a}}$ & $28.2 \pm 1.55^{\mathrm{a}}$ \\
LR [\%] & $24.2 \pm 0.98^{\mathrm{d}}$ & $19.8 \pm 1.10^{\mathrm{c}}$ & $11.8 \pm 0.75^{\mathrm{a}}$ & $15.5 \pm 0.81^{\mathrm{b}}$ \\
SR [\%] & 100.0 & 100.0 & 100.0 & 100.0 \\
\hline
\end{tabular}

${ }^{1}$ Values are means \pm standard deviation from triplicate groups of fish, and the means in each row with the same superscript are not significantly different $(P \leq 0.05)$. 
Proximate composition of fish carcass [\% wet weight] before and after the growth test ${ }^{1}$

\begin{tabular}{lrrrrr}
\hline & \multirow{2}{*}{$\begin{array}{c}\text { Before the } \\
\text { Parameter }\end{array}$} & \multicolumn{4}{c}{ After the growth test } \\
\cline { 3 - 5 } & growth test & \multicolumn{4}{c}{ Treatment } \\
\cline { 3 - 5 } & $17.6 \pm 0.51^{\mathrm{a}}$ & $30.8 \pm 1.22^{\mathrm{c}}$ & $26.2 \pm 0.88^{\mathrm{b}}$ & $28.6 \pm 1.09^{\mathrm{b}}$ & $27.3 \pm 1.05^{\mathrm{b}}$ \\
Dry mass & $1.9 \pm 0.18^{\mathrm{a}}$ & $2.1 \pm 0.20^{\mathrm{a}}$ & $2.3 \pm 0.18^{\mathrm{a}}$ & $2.4 \pm 0.21^{\mathrm{a}}$ & $2.7 \pm 0.19^{\mathrm{a}}$ \\
Ash & $11.6 \pm 0.25^{\mathrm{a}}$ & $13.6 \pm 0.35^{\mathrm{b}}$ & $13.6 \pm 0.23^{\mathrm{b}}$ & $13.2 \pm 0.19^{\mathrm{b}}$ & $13.1 \pm 0.10^{\mathrm{b}}$ \\
Crude protein & $2.7 \pm 0.19^{\mathrm{a}}$ & $13.2 \pm 0.88^{\mathrm{d}}$ & $8.4 \pm 0.79^{\mathrm{b}}$ & $11.2 \pm 1.10^{\mathrm{cd}}$ & $9.9 \pm 0.96^{\mathrm{bc}}$ \\
Crude fat & & &
\end{tabular}

${ }^{1}$ Values are means \pm standard deviation from triplicate groups of fish, and the means in each row with the same superscript are not significantly different $(P \leq 0.05)$.

\section{DISCUSSION}

The rearing success of juvenile fish stages depends on many factors, which are generally defined as welfare. The possibility of modifying the basic environmental parameters, such as temperature and oxygen content and maintaining them on an optimal level is very crucial for a culture setup. Temperature of water during the experiment was maintained on a relatively constant level $\left(22-23^{\circ} \mathrm{C}\right)$, and the water oxygen saturation dropped below $70 \%$. Wels catfish, being a warm-water predator, grows best at high water temperatures. The catfish breeding specialists provide different ranges of the optimum temperature in which this species reaches the highest increments. Wolnicki and Myszkowski (1998) argued that the lower limit of the temperatures recommended for use in the rearing of catfish fry is $25^{\circ} \mathrm{C}$. Below this temperature, the growth of the fry can be by about $30-50$ percentage points worse than at the temperature of $28-30^{\circ} \mathrm{C}$. The same authors believe also that for the older developmental stages of catfish, a slightly lower water temperature can be used than in the fry rearing, ranging from 22 to $26^{\circ} \mathrm{C}$. On the other hand, Ulikowski (2003) stated that catfish shows the best increments at water temperatures of $23-30^{\circ} \mathrm{C}$.

According to Ulikowski (2005), the best effects in catfish breeding are obtained using a day-and-night feeding with the application of automatic feeders, which had been confirmed by the results obtained by Bolliet et al. (2001). During the presently described experiment, wels catfish were fed for $24 \mathrm{~h}$ (automatic feeders with a clock drive). The feed consumption was not affected by the day light, because the walls of tank were painted with a grey paint and the aquarium compound was sparsely illuminated. The characteristic 'lazy' behaviour of the catfish may be beneficial for the culture results, because when they are satiated, they stay almost motionless at the bottom of the reservoir and thereby they do not loose unnecessarily their energy (Boujard 1995). Without any doubts, it exerts an influence on the use of the nutritive components of the feed, expressed by low FCR value (during the whole experiments, the mean FCR value was one).

The optimal level of total protein, in the feed used for catfish fry rearing, has been determined as $40-45 \%$ (Mareš et al. 2003, Has-Schön et al. 2004). Analyzing the results of experiments referring to the feeding of catfish
(Wolnicki et al. 1998), the aim to determine the optimal crude fat content in the feed is justified. Feeding experiment carried out by Filipiak et al. (1993) confirmed that catfish are able to utilize fat in a significantly better way than carbohydrates. Different results were obtained in carp feeding, proving that carp utilize feed carbohydrates significantly better, transforming them into tissue fat. Studies of Cowey and Sargent (1979) indicated a general tendency of a poorer utilization of carbohydrates by poikilotherms in comparison with homeothermic animals. The reason for the above is the low activity of the hexokinase - the enzyme involved in the metabolism of sugars. Furthermore, a side effect of the production of high-carbohydrate level feed mixes may be the Mallard's reaction (Plakas et al. 1985), responsible for creation of bonds between amino acids and carbohydrates limiting their digestibility and assimilability.

The available relevant publications emphasize the necessity of a careful dosing of fat in the feed given to catfish. Sadowski (2005) argued that fat beside protein, constitutes the main source of energy in wels catfish. The above author states that in spite of that, the requirement for fat in the feed is not high. Breeding experiments of catfish in water previously used for cooling purposes indicate that the requirement of catfish for lipids is about $13 \%$ at the temperature of $20-23^{\circ} \mathrm{C}$ and $17 \%$ at $24-30^{\circ} \mathrm{C}$. It is commonly known that catfish can be fed with a feed containing $20 \%$ and even $25 \%$ of fat obtaining FCR values below 1 . It seems to be economically justified to use feeds with a lower content of fat, because it has no negative effect on the composition of the body (meat) of catfish.

Correctly balanced feeds for a fish species should not only cover the quantitative requirements for lipids but should also include the necessary composition of fat fractions. The demand of warm-water fish for two essential fatty acids (EFA): the linoleic and linolenic amounts to $0.5 \%-1.0 \%$ in the dry diet (Takeuchi and Watanabe 1977, Stickney and Hardy 1989, Kaushik 1995). The relation between omega- 3 and omega- 6 fatty acids is also of great importance for some fish species, i.e., common carp (Randuz-Neto et al. 1993). Different types of fat raw materials used in fish feeds contain an amount of EFA specific for them. A comparatively high content of linoleic and arachidonic acids are found in vegetable oils, while 
marine animal fats, as well as linseed, rapeseed, and soybean oils constitute a valuable source of linolenic acid. The proper selection of fat raw materials has a deciding effect on the qualitative composition of dietary lipids. According to the manufacturer's data, the fat sources in the feeds tested in the present experiment included both the fish oil as well as vegetable oils. A joint application in the diets of fats both of animal and plant origin insures the meeting of fish requirements for fatty acids.

Studies of Jankowska et al. (2004) indicate that the application of artificial feeds in intensive breeding can positively change the chemical composition of the meat of predatory fish species, including wels catfish. Chemical composition of the meat of wels catfish from intensive breeding (fish fed commercial rainbow trout feed) and obtained from natural environment (fish fed natural food in natural ponds) did not differ in the total content of saturated and not saturated acids. In wels catfish from both mentioned above environments, the share of saturated fatty acids amounted to about $25 \%$ of all fatty acids, while the share of mono-unsaturated and poly-unsaturated acids amounted to $38 \%$ and $35 \%$, respectively. On the other hand, differences referred to the content of fatty acids in all earlier mentioned groups. The level of fatty acids important for the human health was definitely higher in wels catfish from intensive breeding (EPA higher by 3 percentage points, DHA higher by 4 percentage points). Thereby, the promotion of cultured fish species (including the wels catfish) is justified, because their meat composition can be more favourable for humans than the meat of wild fishes obtained from natural bodies of water. This assumption was confirmed by Bogut et al. (2002).

The catfish fed 20\%-fat-content feed attained the highest individual weights. Differentiated amounts of dietary lipids in the diet did not exert any effect on the rate of fish growth or on the proper utilization of the nutritive components in feeds. The present results emphasize the complexity of the wels catfish nutrition study and the need for further investigation in this field. From a practical point of view, a good understanding of the species requirement for dietary lipids would be of prime interest for fish farmers to use balanced feed optimized for particular fish stages.

\section{REFERENCES}

Bogut I., Has-Schön E., Čačić M., Milaković Z., Novoselić D., Brkić S. 2002. Linolenic acid supplementation in the diet of European catfish (Silurus glanis): effect on growth and fatty acid composition. Journal of Applied Ichthyology 18: $1-6$.

Bolliet V., Aranda A., Boujard T. 2001. Demand-feeding rhythm in rainbow trout and European catfish. Synchronization by photoperiod and food availability. Physiology and Behavior 73: 625-633.

Boujard T. 1995. Diel rhythms of feeding activity in the European catfish, Silurus glanis. Physiology and Behaviour 58: 641-645.
Cowey C.B., Sargent J.R. 1979. Nutrition. In: Hoar W.S., Randall D.J., Brett J.R. (eds.) Fish physiology. Vol. VIII. Bioenergetics and growth. Academic Press, New York.

Filipiak J., Trzebiatowski R., Sadowski J. 1993. Wpływ różnej zawartości białka ogólnego w paszach na wzrost i skład chemiczny ciała suma europejskiego (Silurus glanis L.) chowanego w sadzach w wodzie pochłodniczej. [The effects of different protein levels on feed utilization and body composition of wels (Silurus glanis L.) cage reared in cooling water.] Zeszyty Naukowe Akademii Rolniczej w Szczecinie (156): 43-54. [In Polish.]

Has-Schön E., Bogut I., Kralik D., Vuković B. 2004. Mutual influence of protein and lipid feed content on European catfish (Silurus glanis L.) growth. Journal of Applied Ichthyology 20: 92-99.

Jankowska B., Zakęś Z., Żmijewski T., Ulikowski D., Kowalska A. 2004. Impact of diet on the fatty acids profile of European catfish (Silurus glanis L.). Archives of Polish Fisheries 12: 99-110.

Kaushik S.J. 1995: Nutrient requirements, supply and utilization in the context of carp culture. Aquaculture 129: 225-241.

Linhart O., Štěch L., Švarc J., Rodina M., Audebert J.P., Grecu J., Billard R. 2002. The culture of the European catfish, Silurus glanis, in the Czech Republic and in France. Aquatic Living Resources 15: 139-144.

Mareš J., Wognarová S., Spurný P. 2003. Evaluation of production efficiency of selected feed mixes at intensive culture of European wels (Silurus glanis L.). Acta Scientiarum Polonorum, Seria Piscaria 2 (1): 183-194.

Plakas S.M., Lee T.-C., Wolke R.E., Meade T.L. 1985. Effect of Maillard browning reaction on protein utilization and plasma amino acid response by rainbow trout (Salmo gairdneri). Journal of Nutrition 115: 1589-1599.

Proteau J.P., Hilge V., Linhart O. 1996. Present state and prospects of the aquaculture of catfishes (Siluroidei) in Europe. Aquatic Living Resources 9: 229-235.

Randuz-Neto J., Corraze G, Bergot P., Kaushik S.J. 1993. Estimation of essential fatty acid requirements of common carp larvae using semipurified artificial diets. Pp. 5-6. In: Workshop on the fatty acid metabolism in the carp. International symposium on the carp. 6-9 September 1993, Budapest, Hungary.

Sadowski J. 2005. Technologia sadzowego chowu suma europejskiego (Silurus glanis L.) w wodach pochłodniczych na przykładzie kanału zrzutowego elektrowni „Dolna Odra”. [European catfish (Silurus glanis L.) cage rearing technology in cooling water of the Dolna Odra Power Plant.] Pp. 55-61. In: Zakęś Z. (ed.) Rozród, podchów, profilaktyka ryb sumowatych i innych gatunków. [Breading, culture, and prophylaxis of siluroid- and other fishes.] Wydawnictwo IRS, Olsztyn. [In Polish.]

Siwicki A. 1984. New anaesthetic for fish. Aquacultue 38: 171-176.

Stickney R.R., Hardy R.W. 1989. Lipid requirements of some warmwater species. Aquaculture 79: 149-156.

Takeuchi T., Watanabe T. 1977. Requirement of carp for essential fatty acids. Nippon Suisan Gakkaishi $=$ Bulletin of the Japanese Society of Scientific Fisheries 43: 541-551. 
Ulikowski D. 2003. Towarowy tucz suma europejskiego (Silurus glanis L.) w obiegach recyrkulacyjnych. [Intensive production of European catfish (Silurus glanis L.) in water recirculating systems.] Komunikaty Rybackie 2003 (2): 10-12. [In Polish.]

Ulikowski D. 2005. Technologia chowu suma europejskiego (Silurus glanis L.) w obiegach recyrkulacyjnych. [Rearing technology of European catfish (Silurus glanis L.) in water recirculating systems.] Pp. 45-54. In: Zakęś Z. (ed.) Rozród, podchów, profilaktyka ryb sumowatych i innych gatunków. [Breeding, culture, and prophylaxis of siluroid- and other fishes.] Wydawnictwo IRS, Olsztyn. [In Polish.]

Ulikowski D., Borkowska I., Szczepkowska B. 1998. Wyniki basenowego i stawowego chowu larw i narybku suma europejskiego (Silurus glanis L.) w Doświadczalnym Ośrodku Zarybieniowym „Dgał”. [Rearing effects of European catfish (Silurus glanis L.) larvae and fry in basins and ponds in the Dgał Experimental Stocking Station.] Komunikaty Rybackie 1998 (2): 3-6. [In Polish.]

Wolnicki J., Myszkowski L. 1998. Survival, growth and food conversion in European wels, Silurus glanis L., larvae fed commercial dry diets at $28^{\circ} \mathrm{C}$. Polskie Archiwum Hydrobiologii $=$ Polish Archives of Hydrobiology 45: 531-538.

Wolnicki J., Przybył A., Starzonek I. 1998: Evaluation of five dry diets for initial feeding of European wels, (Silurus glanis L.), larvae under controlled conditions. Archives of Polish Fisheries 6 (1): 123-133.

Vallod D. 1987. Le silure (Silurus glanis). Bulletin de Association pour le Développement de l'Aquaculture No. 16.

Received: 15 April 2008

Accepted: 15 May 2008

Published electronically: 30 November 2008 